\title{
Enemies Within
}





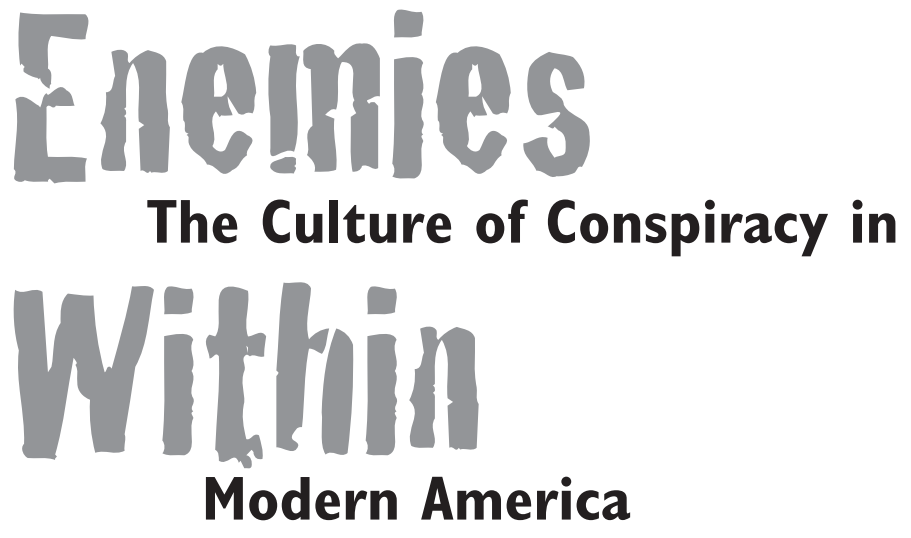

ROBERT ALAN GOLDBERG

YALE UNIVERSITY PRESS

NEW HAVEN \& LONDON 
Copyright (ㄷ 2001 by Yale University.

All rights reserved.

This book may not be reproduced, in whole or in part, including illustrations, in any form (beyond that copying permitted by Sections 107 and 108 of the U.S. Copyright Law and except by reviewers for the public press), without written permission from the publishers.

Designed by James Johnson and set in Swift Roman, Gill Sans, and Crackhouse types by Achorn Graphic Services, Inc. Printed in the United States of America by R. R. Donnelley \& Sons.

Library of Congress Cataloging-in-Publication Data Goldberg, Robert Alan, 1949Enemies within : the culture of conspiracy in modern America / Robert A. Goldberg p. $\mathrm{cm}$. Includes bibliographical references and index. ISBN 0-300-09000-5 (cloth : alk. paper)

1. Conspiracies-United States-History. 2. United States-Social conditions.

3. United States-Politics and government. I. Title.

HV6285 .G65 2001

973-dc21

200100008

A catalogue record for this book is available from the British Library.

The paper in this book meets the guidelines for permanence and durability of the Committee on Production Guidelines for Book Longevity of the Council on Library Resources.

$\begin{array}{llllllllll}1 & 2 & 3 & 4 & 5 & 6 & 7 & 8 & 9 & 10\end{array}$ 
For Annie 
